\title{
Characterization of a Fibrinolytic Enzyme Secreted by Bacillus velezensis BS2 Isolated from Sea Squirt Jeotgal|s
}

\author{
Zhuang Yao ${ }^{1}$, Jeong A Kim ${ }^{1}$, and Jeong Hwan Kim ${ }^{1,2 *}$ \\ ${ }^{1}$ Division of Applied Life Science (BK21 PLUS), Graduate School, Gyeongsang National University, Jinju 52828, Republic of Korea \\ ${ }^{2}$ Institute of Agriculture and Life Science, Gyeongsang National University, Jinju 52828, Republic of Korea
}

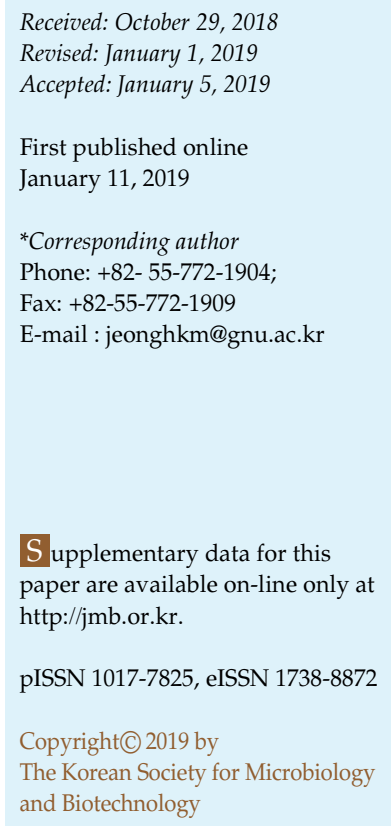

S upplementary data for this paper are available on-line only at http://jmb.or.kr.

pISSN 1017-7825, eISSN 1738-8872

Copyright(C) 2019 by

The Korean Society for Microbiology and Biotechnology

Bacillus sp. BS2 showing strong fibrinolytic activity was isolated from sea squirt (munggae) jeotgal, a traditional Korean fermented seafood. BS2 was identified as B. velezensis by molecular biological methods. B. velezensis BS2 grows well at $15 \% \mathrm{NaCl}$ and at $10^{\circ} \mathrm{C}$. When B. velezensis BS2 was cultivated in TSB broth for $96 \mathrm{~h}$ at $37^{\circ} \mathrm{C}$, the culture showed the highest fibrinolytic activity $(131.15 \mathrm{mU} / \mu \mathrm{l})$ at $96 \mathrm{~h}$. Three bands of 27, 35 and $60 \mathrm{kDa}$ were observed from culture supernatant by SDS-PAGE, and fibrin zymography showed that the major fibrinolytic protein was the $27 \mathrm{kDa}$ band. The gene (aprEBS2) encoding the major fibrinolytic protein was cloned, and overexpressed in heterologous hosts, B. subtilis WB600 and E. coli BL21 (DE3). B. subtilis transformant showed 1.5-fold higher fibrinolytic activity than B. velezensis BS2. Overproduced AprEBS2 in E. coli was purified by affinity chromatography. The optimum $\mathrm{pH}$ and temperature were $\mathrm{pH} 8.0$ and $37^{\circ} \mathrm{C}$, respectively. $\mathrm{K}_{\mathrm{m}}$ and $\mathrm{V}_{\max }$ were $0.15 \mathrm{mM}$ and $39.68 \mu \mathrm{M} / 1 / \mathrm{min}$, respectively, when $\mathrm{N}$-succinyl-Ala-Ala-Pro-Phe-pNA was used as the substrate. AprEBS2 has strong $\alpha$-fibrinogenase and moderate $\beta$-fibrinogenase activity. Considering its high fibrinolytic activity, significant salt tolerance, and ability to grow at $10^{\circ} \mathrm{C}$, B. velezensis BS2 can be used as a starter for jeotgal.

Keywords: Bacillus velezensis, fibrinolytic activity, sea squirt jeotgal, salt tolerance

\section{Introduction}

Jeotgal is a traditional Korean fermented seafood prepared from various fishes, fish eggs, fish intestines, squids, and shellfishes. Most types of jeotgal are made simply by mixing the raw materials with salt and preserving them for several months before consumption [1]. Various microorganisms have been isolated from jeotgal, and identified by cultural methods and/or culture-independent methods [2-6]. Due to the high salinity of most jeotgal types $(20-30 \%, \mathrm{NaCl})$, halophilic and halotolerant microorganisms can grow during jeotgal fermentation, and they are believed to contribute to the development of the varied and unique flavors of jeotgal. Halophiles such as Tetragenococcus sp. or Halanaerobium sp. and halotolerant organisms such as Staphylococcus sp. are the most often isolated organisms [2,3]. Even though the growth of nonhalophiles is inhibited, some nonhalophiles such as
Bacillus sp. still persist during the whole fermentation process [2, 3]. Various species have been identified as dominant species for jeotgal by both culture dependent and independent methods, but the exact roles of each species for jeotgal fermentation are not understood well.

It is generally believed that microorganisms with strong proteolytic activities can accelerate fermentation processes, thus reducing the time required for the completion of fermentation of fish sauce and jeotgal [7]. Proteases from both raw materials and microorganisms hydrolyze the proteins of the raw materials, generating amino acids, peptides and important metabolites and also affect the overall quality of fermented foods $[8,9]$. In this respect, Bacillus sp. are promising candidates as starters for jeotgal because they secrete several active proteases into the culture medium. Some bacilli secrete proteases with fibrinolytic activities into the culture medium, and nattokinase produced by some $B$. subtilis strains is the most well known 
[10]. Other Bacillus species such as B. amyloliquefaciens and $B$. licheniformis also secrete enzymes quite similar with nattokinase [11]. Bacilli producing such fibrinolytic enzymes have an advantage as starters for fermented foods since the enzymes not only contribute to successful progress of fermentation by hydrolyzing proteins but also increase the functionalty of fermented foods [12]. Another essential requirement for a starter is the ability to grow under the high salinity of jeotgal. Many bacilli can't grow in high salt environments $(10 \% \mathrm{NaCl}$ or above) but remain as inactive or dormant cells [3]. Some bacilli cells can persist under high salinity conditions and resume rapid growth when conditions are changed favorably. B. subtilis JS2 was isolated from saeu (small shrimp) jeotgal and the strain grew in LB broth with $20 \%(\mathrm{w} / \mathrm{v}) \mathrm{NaCl}$ [13]. When B. subtilis JS2 was inoculated into gul (oyster) jeotgal ( $23 \%$ $\mathrm{NaCl}, \mathrm{w} / \mathrm{v})$ as a starter $\left(1 \times 10^{6} \mathrm{CFU} / \mathrm{g}\right.$ jeotgal $)$, it did not grow but some cells remained viable during 24 weeks of fermentation [13]. Considering their strong proteolytic activities, halotolerant bacilli are promising as starters for jeotgal and other fermented foods such as soy sauce. In addition to strong proteolytic activities, many bacilli produce antimicrobial substances, which effectively prevent the growth of pathogenic fungi and bacteria. Also, bacilli form spores, which can last for long periods under adverse conditions.

Bacillus velezensis BS2 was isolated from sea squirt (munggae) jeotgal, and the strain showed significant fibrinolytic activity, salt tolerance, antimicrobial activity, and ability to grow at $10^{\circ} \mathrm{C}$. A fibrinolytic gene, aprEBS2, was cloned and overexpressed in B. subtilis and E. coli. AprEBS2 overproduced in E. coli was purified and its properties were studied. Considering these results, B. velezensis BS2 seems promising as a starter for jeotgal, accelerating fermentation and improving final quality.

\section{Materials and Methods}

\section{Isolation and Identification of Bacillus sp. BS2}

Bacilli with fibrinolytic activities were isolated from sea squirt (munggae) jeotgal. Sea squirt was purchased at a local fish store at Tongyeong, Gyeongnam, Korea in the spring of 2018. After washing with tap water, sea squirt was mixed with salt, and the final salt concentration was $12 \%(w / w)$. Sea squirt jeotgal was fermented for 42 days at $10^{\circ} \mathrm{C}$. During fermentation, $10 \mathrm{~g}$ of jeotgal was taken out, mixed with $90 \mathrm{ml}$ of $0.1 \%$ peptone water, and homogenized by Stomacher 80 (Seward, Worthing, UK). Diluted samples were spread on tryptic soy broth (TSB, Becton, Dickinson and Company, Sparks, USA) agar plates with $\mathrm{NaCl}(10 \%, \mathrm{w} / \mathrm{v})$. Plates were incubated for $48 \mathrm{~h}$ at $37^{\circ} \mathrm{C}$, and colonies were spotted onto Luria-Bertani (LB, tryptone $10 \mathrm{~g}$, yeast extract $5 \mathrm{~g}, \mathrm{NaCl} 5 \mathrm{~g} / \mathrm{l}$, $\mathrm{pH} 7.0)$ agar plates with skim milk (1\%,w/v). Colonies showing big halos were further examined for fibrinolytic activities by fibrin plate method (see below).

$16 \mathrm{~S}$ rRNA genes were amplified by using the following primers: bac-F (5'-CGGCGTGCCTAATACATGCAAG-3') and bac-R (5'GGCATGCTG ATCCGCATTAC TA-3') [14]. A partial recA gene was amplified using primers: recA-F (5'-TGAGTGATCGTCAGG CAGCCTTAG-3') and recA-R (5'-CYTBRGATAAGAR TACCAW GMACCGC-3') [14]. Amplification was done using a thermocycler (MJ Mini Personal Thermal Cycler, BioRad, USA). Reaction mixture $(50 \mu \mathrm{l})$ contained $1 \mu \mathrm{l}$ of template DNA, $1 \mu \mathrm{l}$ of each primer $(10 \mu \mathrm{M}), 5 \mu \mathrm{l}$ of dNTPs $(0.25 \mathrm{mM})$, and $0.5 \mu \mathrm{l}$ of ExTaq DNA polymerase (Takara, Japan). Amplification conditions were as follows: initial denaturation at $94^{\circ} \mathrm{C}$ for $5 \mathrm{~min}$ followed by 30 cycles of $94^{\circ} \mathrm{C}$ for $30 \mathrm{sec}, 58^{\circ} \mathrm{C}$ for $30 \mathrm{sec}, 72^{\circ} \mathrm{C}$ for $40 \mathrm{sec}$, and a final extension at $72^{\circ} \mathrm{C}$ for $5 \mathrm{~min}$. Nucleotide sequences of the amplified fragments were determined and searched for homologous genes by BLAST (NCBI, USA).

RAPD-PCR was done using S30 (5'-GTGATCGCAG-3') as a primer and chromosomal DNA as a template. Chromosomal DNA was prepared from $18 \mathrm{~h}$ culture on LB broth by phenol-chloroform extraction method, and PCR was done as reported previously [15].

\section{Growth, Fibrinolytic Activity, and Salt Tolerance of B. velezensis BS2}

B. velezensis BS2 was grown in 4 different media: LB broth, Brain Heart Infusion (BHI, Becton, Dickinson and Company), nutrient broth (NB, Becton, Dickinson and Company), and TSB. Aliquots were taken at $12 \mathrm{~h}$ intervals during $96 \mathrm{~h}$ cultivation at $37^{\circ} \mathrm{C}$ with shaking, and $\mathrm{OD}_{600 \mathrm{~nm}}$ values were measured using a spectrophotometer (UV-1601, Shimadzu, Japan). Aliquots were centrifuged at $4,000 \times g$ for $10 \mathrm{~min}$ at $4^{\circ} \mathrm{C}$, and the supernatant was filtered using a $0.45 \mu \mathrm{m}$ filter (Sartorius Stedim, Germany). Filtered supernatant (FS) was assayed for fibrinolytic activity by fibrin plate method [14]. The size of lysis zones on fibrin plates were converted into plasmin units $(\mathrm{U})$ by comparing them with those of plasmin with different units (Sigma, USA). Salt tolerance of B. velezensis BS2 was examined by checking growth in LB broth with $\mathrm{NaCl}$. B. velezensis BS2 was grown overnight in $\mathrm{LB}(1 \%, \mathrm{v} / \mathrm{v})$, and then inoculated into fresh TSB broth with different $\mathrm{NaCl}$ concentrations $(10,12,15,17,20 \%, \mathrm{w} / \mathrm{v})$. Cultures were incubated for $96 \mathrm{~h}$ with shaking at $37^{\circ} \mathrm{C}$, and $\mathrm{OD}_{600}$ values were measured at $12 \mathrm{~h}$ intervals.

\section{SDS-PAGE and Fibrin Zymography}

B. velezensis BS2 was grown in TSB for $96 \mathrm{~h}$ at $37^{\circ} \mathrm{C}$. Aliquots were taken at intervals, and FSs were obtained. FSs were boiled for $5 \mathrm{~min}$ in $4 \times$ SDS sample buffer (12 g Tris base, $57.6 \mathrm{~g}$ glycine, $4 \mathrm{~g} / \mathrm{l}$ SDS). SDS-PAGE was done using a $10 \%$ acrylamide gel, and fibrin zymography was done using a polyacryamide gel containing fibrin, which was prepared by mixing fibrinogen $(0.12 \%, \mathrm{w} / \mathrm{v})$ and $100 \mu \mathrm{l}$ of thrombin $(10 \mathrm{NIH}$ units/ml) with 
acrylamide solution. After electrophoresis at a constant current of $10 \mathrm{~mA}$ in a cold room, the fibrin gel was soaked in $50 \mathrm{mM}$ Tris$\mathrm{HCl}$ buffer ( $\mathrm{pH} 7.4$ ) containing $2.5 \%$ Triton $\mathrm{X}-100$ for $30 \mathrm{~min}$ at room temperature on a rotary shaker. Gel was washed with distilled water for $30 \mathrm{~min}$ to remove Triton X-100 and soaked in zymogram reaction buffer $(30 \mathrm{mM}$ Tris- $\mathrm{HCl}, \mathrm{pH} 7.4,0.02 \%$ of $\mathrm{NaN}_{3}$ ) for $12 \mathrm{~h}$ at $37^{\circ} \mathrm{C}$. Finally, the gel was stained with coomassie blue R-250 [14].

\section{Cloning of aprEBS2 Gene}

aprEBS2 was amplified from $B$. velezensis BS2 genome by using a primer pair: CH51-F (5'-AGGATCCCAAGAGAGCGATTGCGG CTGTGTAC-3', BamHI site underlined) and CH51-R (5'AGAATTCTTCAGAGGGAGCCACCCGTCGATCA-3', EcoRI site underlined) [16]. PCR was done as described above except annealing temperature was $65^{\circ} \mathrm{C}$. Amplified fragment was ligated with pHY300PLK $\left(4.87 \mathrm{~kb}, \mathrm{Tc}^{\mathrm{R}}\right.$ ) (Takara) after being digested with $B a m \mathrm{HI}$ and EcoRI. Ligation mixture was used to transform B. subtilils WB600 competent cells by electroporation. A B. subtilis transformant (TF) was grown in LB broth containing tetracycline $(10 \mu \mathrm{g} / \mathrm{ml})$. Growth and fibrinolytic activity were measured at intervals during $96 \mathrm{~h}$ cultivation. Preparation of B. subtilils WB600 competent cells and electroporation $(200 \Omega, 18 \mathrm{kV} / \mathrm{cm})$ were done according to published methods [17]. Plasmid DNA preparation, restriction enzyme digestion, and agarose gel electrophoresis were done according to published methods [18].

\section{Overexpression of aprEBS2 in E. coli and Purification of Recombinant AprEBS2}

aprEBS2 without its own signal sequence was amplified using the following primer pairs: pETBS2-F (5'-AGAGGATCCGATGGC AGGGAAATC-3' BamHI site underlined) and pETBS2-R (5'AGACTCGAGCTGAGCTGCCGCCTG-3' XhoI site underlined). Amplified gene was inserted into pET26b (+) (Merck Millipore, Germany), resulting in pETBS2. An E. coli BL21 (DE3) TF harboring pETBS2 was obtained by electroporation, and grown in LB $(250 \mathrm{ml})$ containing kanamycin $(30 \mu \mathrm{g} / \mathrm{ml})$. When the $\mathrm{OD}_{600}$ reached 0.8 , IPTG (isopropyl $\beta$-D-1-thiogalactopyranoside) was added $(1 \mathrm{mM})$, and culture was incubated for $20 \mathrm{~h}$. Cells were obtained by centrifugation, resuspended in $5 \mathrm{ml}$ of PBS, and then disrupted by sonication (UW 2070, Bandelin, Germany). Cell extract was centrifuged at $8,000 \times g$ for $15 \mathrm{~min}$ at $4^{\circ} \mathrm{C}$. Soluble fraction (supernatant) and insoluble fraction (pellet) were examined by SDS-PAGE. Insoluble fraction was resuspended with binding buffer ( $20 \mathrm{mM}$ sodium phosphate, $0.5 \mathrm{M} \mathrm{NaCl}, 10 \mathrm{mM}$ imidazole, pH 7.4) and loaded onto a HiTrap IMAC FF column (GE Healthcare, Sweden). Sodium phosphate buffer (20 mM, pH 7.4) containing imidazole and $0.5 \mathrm{M} \mathrm{NaCl}$ was used as elution buffer, and the imidazole concentration was increased from $50 \mathrm{mM}$ to $500 \mathrm{mM}$ with $50 \mathrm{mM}$ intervals. One microliter of each fraction $(1 \mathrm{ml})$ was spotted onto a fibrin plate and incubated at $37^{\circ} \mathrm{C}$. Active fractions were pooled and dialyzed against $20 \mathrm{mM}$ sodium phosphate buffer ( $\mathrm{pH} 7.4$ ) for $24 \mathrm{~h}$. AprEBS2 was concentrated by using an Amicon filter (MWCO 12,000; Millipore). Protein concentration was measured by Bradford method using bovine serum albumin (BSA) as a standard [19].

\section{Properties of Purified AprEBS2}

The effect of $\mathrm{pH}$ on AprEBS2 was examined by using different buffer systems (50 mM): citrate- $\mathrm{NaOH}, \mathrm{pH} 3-5$; sodium phosphate, pH 6-8; and Tris-HCl, pH 9-11. AprEBS2 $(1 \mu \mathrm{g})$ resuspended in each buffer was incubated for $1 \mathrm{~h}$ at $37^{\circ} \mathrm{C}$, and the activity was measured by the fibrin plate method. For measuring $\mathrm{pH}$ stability, AprEBS2 $(1 \mu \mathrm{g})$ in each buffer was incubated up to $6 \mathrm{~h}$ at $37^{\circ} \mathrm{C}$, and activity was measured at 1,3 , and $6 \mathrm{~h}$. AprEBS2 $(1 \mu \mathrm{g})$ in sodium phosphate buffer ( $\mathrm{pH} 8.0$ ) was incubated for $30 \mathrm{~min}$ at $37-60^{\circ} \mathrm{C}$, and then the activity was measured. For measuring thermal stability, AprEBS2 $(1 \mu \mathrm{g})$ in sodium phosphate buffer $(\mathrm{pH}$ 8.0) was incubated up to $3 \mathrm{~h}$ at $37-60^{\circ} \mathrm{C}$, and the remaining activity was measured at $0.5,1,2$, and $3 \mathrm{~h}$. AprEBS2 was exposed to $5 \mathrm{mM}$ metal ions or $1 \mathrm{mM}$ inhibitors for $30 \mathrm{~min}$ at $37^{\circ} \mathrm{C}$ and $\mathrm{pH}$ 8.0 , and the remaining activity was measured.

\section{Amidolytic Activity Measurements and Enzyme Kinetics}

The amidolytic activity of AprEBS2 was examined by using Nsuccinyl-ala-ala-pro-phe-p-nitroanilide (S7388, Sigma). Fifty $\mu$ l of substrate in sodium phosphate buffer ( $50 \mathrm{mM}, \mathrm{pH} 8.0)$ was mixed with AprEBS2 $(1 \mu \mathrm{g})$, and the total volume was adjusted to $500 \mu \mathrm{l}$ with sodium phosphate buffer. After $10 \mathrm{~min}$ incubation at $37^{\circ} \mathrm{C}$, $500 \mu$ l of citrate- $\mathrm{NaOH}$ buffer ( $\mathrm{pH}$ 3.0) was added and the tube was put on ice immediately. The mixture was centrifuged at $12,000 \times g$ for $5 \mathrm{~min}$ and $\mathrm{OD}_{410 \mathrm{~nm}}$ of the supernatant was measured. The degree of hydrolysis was calculated from the absorbance value and the molar extinction coefficient of $p$-nitroanilide $\left(8,800 \mathrm{M}^{-1} \mathrm{~cm}^{-1}\right)$. Kinetic parameters of AprEBS2 were determined by measuring the release of $p$-nitroaniline from $\mathrm{N}$-succinyl-ala-alapro-phe-p-nitroanilide in sodium phosphate buffer at $37^{\circ} \mathrm{C} . \mathrm{V}_{\max }$ and $\mathrm{K}_{\mathrm{m}}$ values were determined from measurements at different substrate concentrations ranging from 0.03 to $0.9 \mathrm{mM}$. $\mathrm{V}_{\max }$ value was converted to $\mathrm{K}_{\text {cat }}$ from the relationship $\mathrm{K}_{\text {cat }}=\mathrm{V}_{\max } /$ [enzyme].

\section{Hydrolysis of Fibrinogen by AprEBS2}

One microgram of fibrinogen (Bovine, MP Biochemicals, Illkirch, France) was mixed with AprEBS2 (50 ng) in $1 \mathrm{ml}$ of sodium phosphate buffer and incubated at $37^{\circ} \mathrm{C}$ up to $6 \mathrm{~h}$. Aliquots were taken out at intervals and mixed with $5 \times$ SDS sample buffer. After boiling for $5 \mathrm{~min}$, samples were analyzed by SDS-PAGE using a $10 \%$ acrylamide gel.

\section{Results and Discussion}

\section{Isolation and Identification of Bacillus sp. BS2}

Among 47 tentative bacilli isolates showing fibrinolytic activities, BS2 produced the largest lytic zone on a fibrin plate (results not shown). BS2 was Gram-positive rod, and 
the colony possessed a typical Bacillus morphology on LB agar plates. 16S rRNA genes were amplified and sequenced (1,225 nucleotides, MH378167). BLAST analysis indicated that the gene showed $99 \%$ identities to genes from B. amyloliquefaciens and B. velezensis strains. A partial recA gene was amplified and the sequence (758 nucleotides, MH378166) also showed $99 \%$ identities to recA genes from B. amyloliquefaciens and B. velezensis strains. Sequencing of $16 \mathrm{~S}$ rRNA and recA genes was not sufficient for accurate species identification. Thus, RAPD (randomly amplified polymorphic DNA)-PCR was done using a S30 primer. Two bands of 800 and 2,000 bp in size were amplified from BS2 chromosomal DNA, and they matched with bands from a $B$. velezensis reference strain (Fig. S1). Another isolate (Bacillus sp. SS2) also showed the same pattern. In contrast, a $1.5 \mathrm{~kb}$ band was amplified from B. amyloliquefaciens reference strain, and the $1.5 \mathrm{~kb}$ band is one of the unique bands of B. amyloliquefaciens strains [15]. From these results, BS2 was positively identified as a B. velezensis strain.

$B$. velezensis is closely related to B. amyloliquefaciens, B. siamensis, and B. methylotrophicus. Because of very high similarities among these species, the exact distinction between these species is controversial [20, 21]. Some $B$. velengensis strains are used to promote plant growth by inhibiting pathogenic fungi $[22,23]$. In addition to plant and soil environments, $B$. velezensis strains have been isolated from marine environments such as sea water and sea mud $[24,25]$. But so far, there has been no report on the isolation of $B$. velezensis from jeotgal. Difficulty in correct species identification among very closely related Bacillus species might be the reason. Considering this, polyphasic classification schemes are necessary for the accurate species identification of bacilli isolates from environmental samples including jeotgal.

\section{Growth, Fibrinolytic Activity, and Salt Tolerance of B. velezensis BS2}

B. velezensis BS2 formed a film at the top of broth when statically cultivated in TSB. The film formation was most obvious at $37^{\circ} \mathrm{C}$ (result not shown), but not observed at $15^{\circ} \mathrm{C}$ and $10^{\circ} \mathrm{C}$. B. velezensis BS2 grew quickly for the first $12 \mathrm{~h}$ at $45^{\circ} \mathrm{C}$ and $\mathrm{OD}_{600}$ value was at the highest point, 1.01, at $12 \mathrm{~h}$. Then the value decreased gradually, reaching 0.86 at $96 \mathrm{~h}$. B. velezensis BS2 grew slowly but steadily at $10^{\circ} \mathrm{C}$, reaching 0.52 at $96 \mathrm{~h}$ (Fig. $1 \mathrm{~A})$. Culture at $37^{\circ} \mathrm{C}$ showed the highest fibrinolytic activity, and culture at $25^{\circ} \mathrm{C}$ showed the second highest activity (Fig. 1B). B. velezensis BS2 produces a bacteriocin that inhibits growth of important food pathogens such as Listeria monocytogenes and B. cereus, an advantage when used as a starter (results not shown).

B. velezensis $\mathrm{BS} 2$ grows well in the presence of $\mathrm{NaCl}$ up to $15 \%(\mathrm{w} / \mathrm{v})$, and slowly at $17 \%$ (Fig. 2). At $15 \% \mathrm{NaCl}$, BS2 did not grow until $48 \mathrm{~h}$, and $\mathrm{OD}_{600}$ was just 0.047 . Then growth started rapidly, and $\mathrm{OD}_{600}$ value was 1.47 at $96 \mathrm{~h}$, the same as those of cultures at $10 \%(1.49)$ or $12 \%(1.52) \mathrm{NaCl}$ (Fig. 2). At $17 \% \mathrm{NaCl}$, B. velezensis BS2 did not grow until $84 \mathrm{~h}$. Then it grew slowly, and $\mathrm{OD}_{600}$ value was 0.26 at $96 \mathrm{~h}$.

Among the 4 culture media tested, TSB was the best medium in terms of cell growth and fibrinolytic activity, and used for further experiments. Culture in TSB showed the highest fibrinolytic activity $(131.15 \mathrm{mU} / \mu \mathrm{l})$ at $96 \mathrm{~h}$, whereas NB was the poorest medium (results not shown).
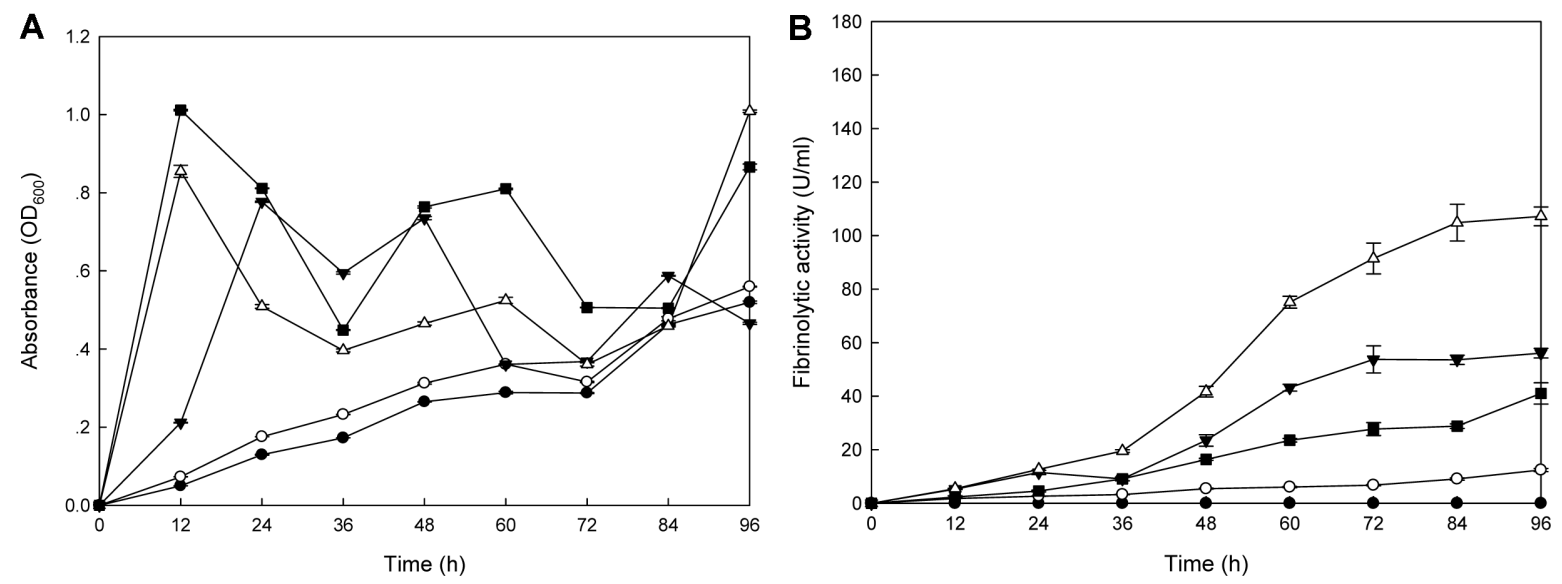

Fig. 1. Effect of temperature on the growth $(\mathbf{A})$ and fibrinolytic activity $(\mathbf{B})$ of $\mathrm{B}$. velezensis $\mathrm{BS} 2 .-\mathbf{O}_{-}, 10^{\circ} \mathrm{C} ;-\bigcirc-, 15^{\circ} \mathrm{C}$; $-\nabla-, 25^{\circ} \mathrm{C}$; $-\triangle-, 37^{\circ} \mathrm{C} ;-\mathbf{-}-, 45^{\circ} \mathrm{C}$.

FS (filtered culture supernatant) at each time point was applied onto a fibrin plate and the fibrinolytic activity was expressed as plasmin unit/ml. 


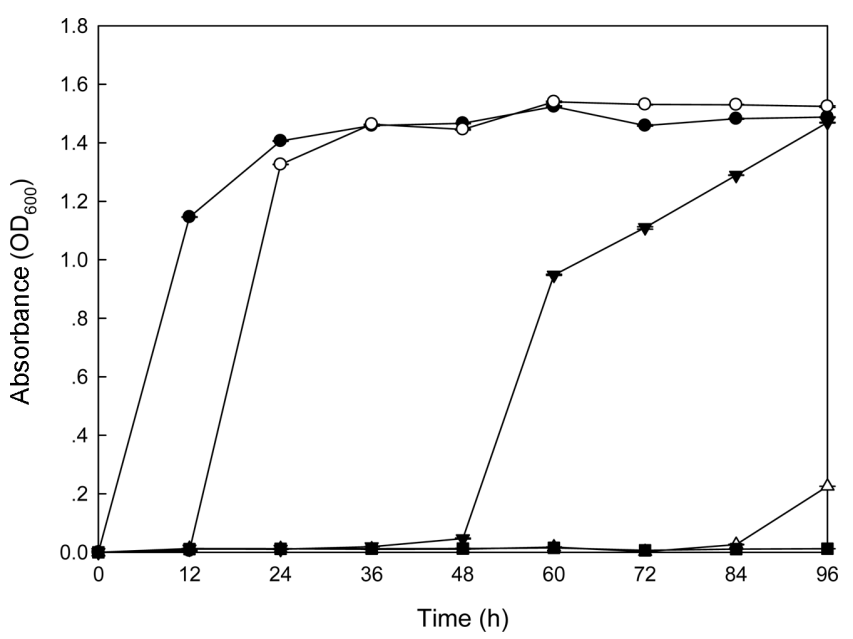

Fig. 2. Salt tolerance of $B$. velezensis BS2.

B. velezensis BS2 was grown in TSB with $\mathrm{NaCl}$ for $96 \mathrm{~h}$ with shaking.

- - , $10 \%$; -,$- 12 \%$; - -, $15 \%$; $\triangle$-, $17 \%$; - - - $20 \% \mathrm{NaCl}$ (w/v).

\section{SDS-PAGE and Fibrin Zymography}

When FS was analyzed by SDS-PAGE, 27, 35, and $60 \mathrm{kDa}$ bands were observed in addition to other bands (Fig. 3A). The $27 \mathrm{kDa}$ band was also observed on a fibrin zymogram and it was the main fibrinolytic protein (Fig. 3B). One notable observation was that the band intensity increased after $72 \mathrm{~h}$, and the strongest intensity was observed at $96 \mathrm{~h}$ (Fig. 3B, lanes 6-8). The result agreed with the fibrinolytic activity measurement results (Fig. 1B). Cultures at 72-96 h showed higher fibrinolytic activities and the cultures showed the strong $27 \mathrm{kDa}$ band by SDS-PAGE. The fibrinolytic activity of culture increased as cells entered into stationary growth phase.

\section{Cloning of aprEBS2 Gene}

The major fibrinolytic protein (AprE) and its gene (aprE) are well conserved among bacilli. The high similarities among aprE genes make it possible to use primer pairs designed for cloning of an aprE gene from a Bacillus species for the cloning of homologous genes from other Bacillus species. In this work, $\mathrm{CH} 51-\mathrm{F}$ and $\mathrm{CH} 51-\mathrm{R}$ primers were used to clone aprEBS2. The primer pairs were initially designed to clone a fibrinolytic gene (aprE51) from B. amyloliquefaciens CH51 [16], and later successfully used to clone aprE34 from B. amyloliquefaciens RSB34 and aprEBS15 from B. pumilus BS15 [14, 26].

A $1.4 \mathrm{~kb}$ amplified fragment was ligated into pHY300PLK, and pHYBS2 $\left(6.2 \mathrm{~kb}, \mathrm{Ap}^{\mathrm{r}}, \mathrm{Tc}^{\mathrm{R}}\right)$ was obtained. Sequencing of the insert (1,359 nucleotides, MH378165) (Fig. S2) confirmed that the gene was a homolog of aprE genes. An ORF of $1,149 \mathrm{bp}$ in size (encoding a protein of 382 amino acids) was located. The first 30 amino acids corresponded to a signal peptide as judged by SignalP 4.1 Server (Technical University of Denmark) and the next 77 amino acids corresponded to a prosequence as judged from comparisons with other fibrinolytic enzymes (results not shown). pI and molecular mass of proAprEBS2 (352 aa) were 8.75 and 35,857.18 Da, respectively. Calculated $\mathrm{pI}$ and molecular mass of mature enzyme were 6.65 and $27429.74 \mathrm{Da}$, respectively. Nucleotide sequence of aprEBS2 showed 99\% identities to those of aprE genes from B. amyloliquefaciens CH51 (EU414203, 1,145/1,149) [16], B. pumilus BS15 (MF943247, 1,144/1,149) [26], and 98\% identities to genes from B. amyloliquefaciens CB1 (KM086575, 1,133/1,149) [27], B. amyloliquefaciens RSB34 (KX098331, 1,132/1,149) [14], and B. amyloliquefaciens MJ5-41 (JF739176, 1,135/1,149) [28]. AprEBS2 showed high similarities with other fibrinolytic

A

B

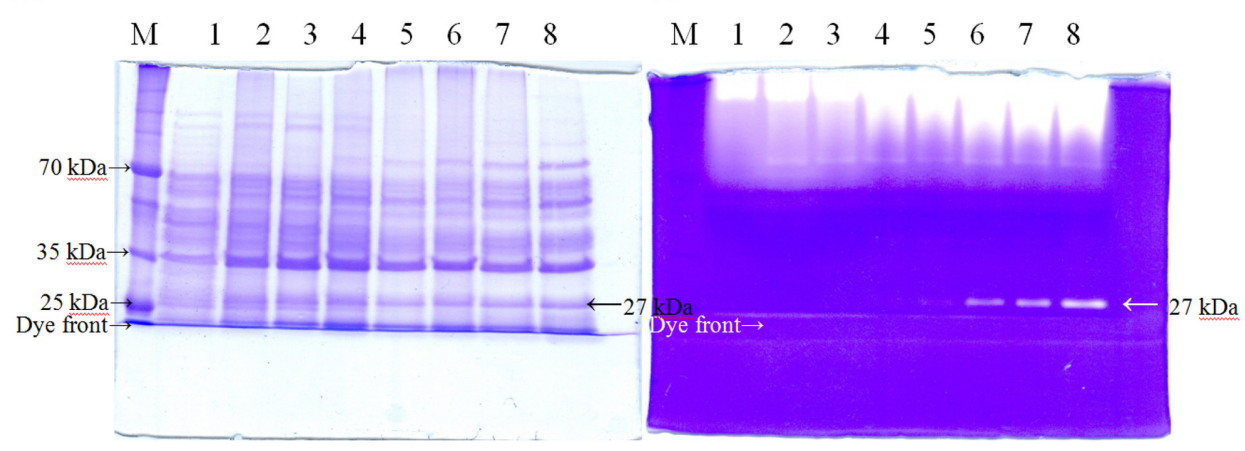

Fig. 3. SDS-PAGE (A) and fibrin zymography (B) of FS from B. velezensis BS2.

B. velezensis BS2 was grown in TSB broth at $37^{\circ} \mathrm{C}$ up to $96 \mathrm{~h}$. FS at each time point was analyzed. M, Dokdo-Marker, broad-range (EBM-1034, ElpisBiotech., Daejeon, Korea); 1, 12 h; 2, 24 h; 3, 36 h; 4, 48 h; 5, 60 h; 6, 72 h; 7, 84 h; 8, 96 h. 

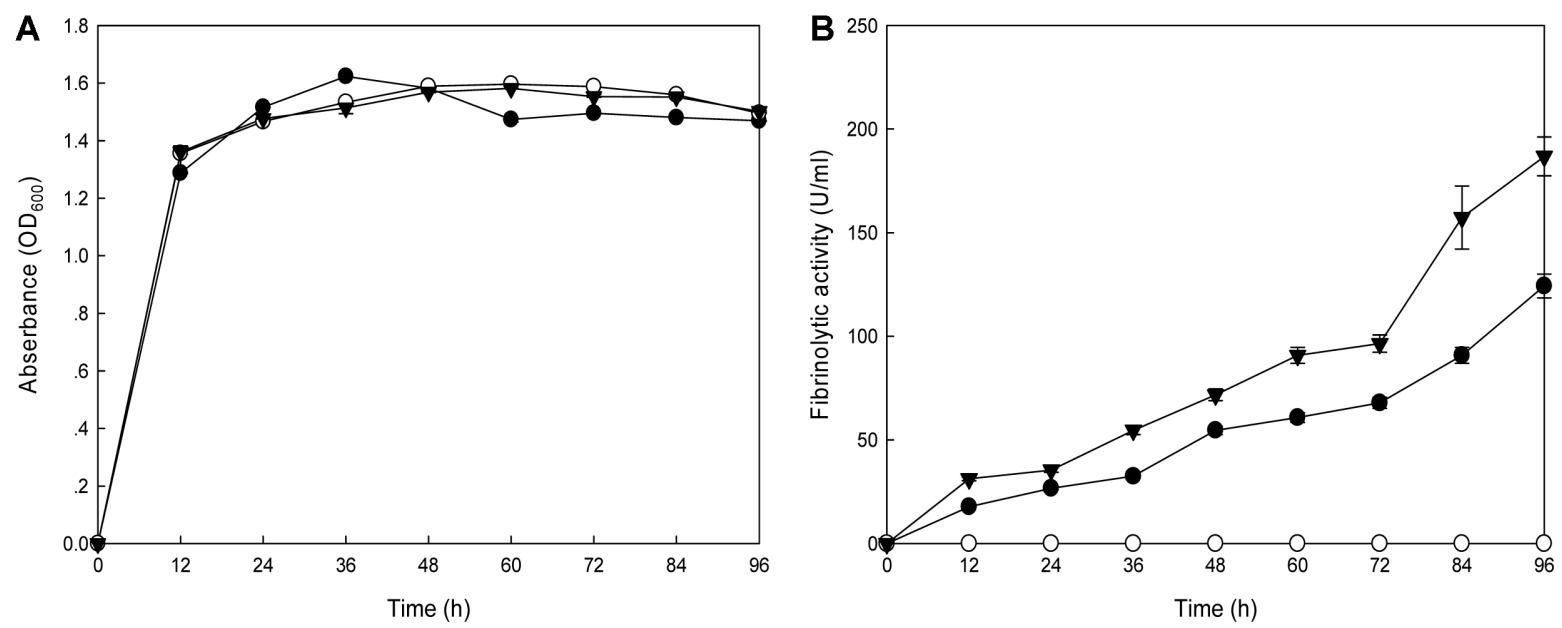

Fig. 4. Growth (A) and fibrinolytic activities (B) of B. subtilis TFs.

B. subtilis WB600 TF was grown for $96 \mathrm{~h}$ at $37^{\circ} \mathrm{C}$ in $\mathrm{LB}$ broth. $\mathrm{OD}_{600}$ and fibrinolytic activities of culture were measured at each time interval. -

B. velezensis BS2; - $\mathbf{-}-$, B. subtilis WB600 [pHYBS2]; - О-, B. subtilis WB600 [pHY300PLK].

enzymes: 99\% with AprE5-41 from B. amyloliquefaciens MJ541 (AEE81297), AprE51 from B. amyloliquefaciens CH51 (ACA34903), AprECB1 from B. amyloliquefaciens CB1 (AIR72259), AprE34 from B. amyloliquefaciens RSB34 (APO13874), and AprEBS15 from B. pumilus BS15 (ATD12229). Amino acids consisting of catalytic triad $\left(\mathrm{Asp}^{32}, \mathrm{His}^{64}\right.$, and Ser ${ }^{221}$ ) are conserved in AprEBS2 like other AprE enzymes [29].

pHYBS2 was introduced into B. subtilis WB600 cells by electroporation [30]. B. subtilis WB600 TF harboring pHYBS2 showed the same growth pattern with B. subtilis WB600 [pHY300PLK] (control) (Fig. 4A), and showed the highest fibrinolytic activity $(186.8 \mathrm{U} / \mathrm{ml})$ at $96 \mathrm{~h}$ (Fig. 4B).
Control did not show any activity. Like the original host, the fibrinolytic activity of B. subtilis WB600 [pHYBS2] increased as culture entered into stationary growth phase. The activity was 1.5 fold higher than that of $B$. velezensis BS2. When FS from B. subtilis TF was analyzed by SDSPAGE and fibrin zymography, proAprEBS2 and mature AprEBS2 were observed (Fig. 5). A 35 kDa proAprEBS2 matched with a $35 \mathrm{kDa}$ band on a coomassie blue-stained gel (Fig. 5A), and the mature AprEBS2 band was observed on a polyacrylamide gel (Fig. 5A) and a fibrin zymogram (Fig. 5B). No $27 \mathrm{kDa}$ band was observed from control, B. subtilis WB600 carrying intact pHY300PLK (Fig. 5, lanes 7-9).

A

B

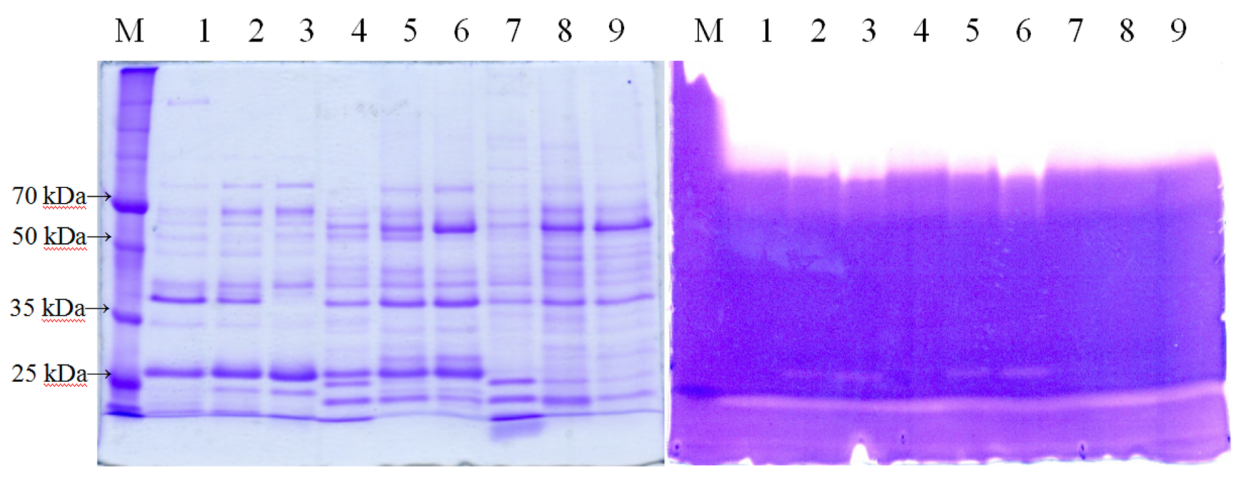

Fig. 5. SDS-PAGE (A) and fibrin zymography (B) of FS from B. subtilis TFs.

M, Dokdo-Marker, broad-range (EBM-1034, Elpis-Biotech., Daejeon, Korea). Bacilli were grown in LB broth at $37^{\circ} \mathrm{C}$ and FSs were analyzed. Lanes 1-3, B.velezensis BS2 grown for $24 \mathrm{~h}$ (lane 1), $60 \mathrm{~h}$ (2), and $96 \mathrm{~h}$ (3); 1anes 4-6, B. subtilis WB600 [pHYBS2] grown for $24 \mathrm{~h}(4), 60 \mathrm{~h}(5)$, and $96 \mathrm{~h} \mathrm{(6);}$ lanes 7-9, B. subtilis WB600 [pHY300PLK] grown for $24 \mathrm{~h} \mathrm{(7),} 60 \mathrm{~h}(8)$, and $96 \mathrm{~h} \mathrm{(9).}$ 

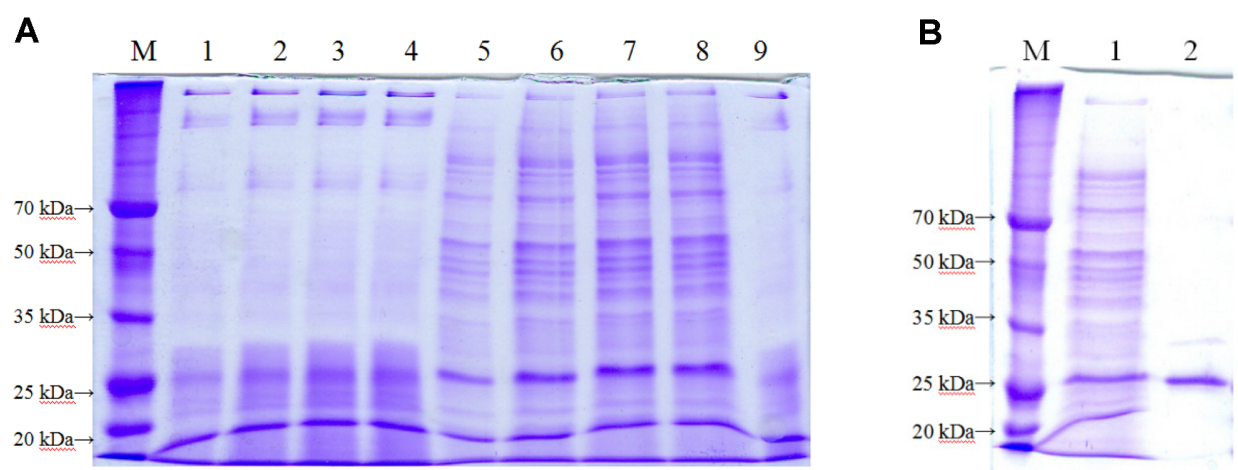

Fig. 6. Overexpression of aprEBS2 in E. coli (A) and purification of AprEBS2 (B).

M, Dokdo-Marker, broad-range (EBM-1034, ELPIS, Daejeon, Korea); Lanes 1-4, soluble fraction from cells grown for 2 (1), 4 (2), 10 (3), and 20 h (4) after induction; Lanes 5-8, insoluble fraction from cells grown for 2 (5), 4 (6), 10 (7), and $20 \mathrm{~h} \mathrm{(8)} \mathrm{after} \mathrm{induction;} \mathrm{9,} \mathrm{negative} \mathrm{control,} \mathrm{soluble} \mathrm{fraction}$ from E. coli BL21 [pETBS2] grown for $20 \mathrm{~h}$ without induction. B. M, Dokdo-Marker, broad-range; 1, insoluble fraction; 2 , purified AprEBS2.

\section{Overexpression of aprEBS2 in E. coli and Purification of Recombinant AprEBS2}

In pETBS2, aprEBS2 has an additional six His codons at the 3' end immediately after the last sense codon (Gln), which was used for the one-step purification of recombinant AprEBS2. After IPTG induction, soluble and insoluble fractions from E. coli BL21 (DE3) with pETBS2 were obtained at different time points and analyzed by SDSPAGE (Fig. 6A). A thick $27 \mathrm{kDa}$ band was observed from the insoluble fraction (Fig. 6A, lanes 5-8). Recombinant AprEBS2 was purified from the insoluble fraction obtained at $20 \mathrm{~h}$ after induction by using a HiTrap IMAC FF column. AprEBS2 was eluted from the column at the imidazole concentration of $350-500 \mathrm{mM}$, and a single $27 \mathrm{kDa}$ protein was obtained (Fig. 6B, lane 2).

\section{Properties of Purified AprEBS2}

The optimum $\mathrm{pH}$ for AprEBS2 was pH 8.0 (Fig. 7A). AprEBS2 maintained higher activity at $\mathrm{pH} 7-10$. The relative activity at $\mathrm{pH} 7,9$, and 10 was $83.8 \%, 97.9 \%$, and $84.5 \%$ of that at $\mathrm{pH} 8.0$, respectively. The enzyme lost activity at $\mathrm{pH} 5$ and below, and the activity declined rapidly at $\mathrm{pH}$ above 10 . AprEBS2 was most stable at $\mathrm{pH} 7-$ 8, and relatively stable at $\mathrm{pH} 9-10$. At $\mathrm{pH} 6$ and 11, AprEBS2 still maintained some activity after $6 \mathrm{~h}$ (Fig. 7B). Activity was completely lost in $1 \mathrm{~h}$ at $\mathrm{pH} 5$ and below. The optimum temperature was $37^{\circ} \mathrm{C}$ (Fig. $7 \mathrm{C}$ ). The activity was lost rapidly at $50^{\circ} \mathrm{C}$ and above, and no activity remained after $30 \mathrm{~min}$ incubation at $60^{\circ} \mathrm{C}$. AprEBS2 was stable at 37$40^{\circ} \mathrm{C}$ and $86.3 \%$ and $67.4 \%$ of activity remained after $3 \mathrm{~h}$ at $37^{\circ} \mathrm{C}$ and $40^{\circ} \mathrm{C}$, respectively (Fig. 7D). Considering the results, AprEBS2 has moderate heat stability. The optimum temperature for AprEBS2 is similar to that for AprEs from other Bacillus strains such as B. subtilis HK176 [31] and B. amyloliquefaciens RSB34 [14], but lower than that for Bacillus sp. strain CK11-4 $\left(70^{\circ} \mathrm{C}\right)$ [32].

The effects of metals and inhibitors on the activity of AprEBS2 were studied (Table 1). $\mathrm{Mg}^{2+}, \mathrm{Ca}^{2+}$, and $\mathrm{Mn}^{2+}$ enhanced the activity by $19.14 \%, 8.21 \%$, and $4.85 \%$, respectively. But the activity was inhibited by $\mathrm{Fe}^{3+}(28.77 \%$ inhibition), $\mathrm{Zn}^{2+}$ (24.62\% inhibition), $\mathrm{K}^{+}$(12.76\% inhibition), and $\mathrm{Co}^{2+}$ (7.35\% inhibition). The fibrinolytic activity was completely inhibited by PMSF (phenylmethylsulfonyl fluoride). But EDTA (ethylenediaminetetraacetic acid), EGTA (ethylene glycol-bis ( $\beta$-aminoethyl ether)- $N, N, N^{\prime}, N^{\prime}$ tetraacetic acid) and SDS (sodium dodecyl sulfate) did not inhibit the activity significantly. AprEBS2 is a serine protease but not a metalloprotease.

Table 1. Effects of metal ions and inhibitors on the activity of AprEBS2.

\begin{tabular}{cccc}
\hline $\begin{array}{c}\text { Metal ions } \\
(5 \mathrm{mM})\end{array}$ & $\begin{array}{c}\text { Relative } \\
\text { activity }(\%)\end{array}$ & $\begin{array}{c}\text { Inhibitors } \\
(1 \mathrm{mM})\end{array}$ & $\begin{array}{c}\text { Relative } \\
\text { activity }(\%)\end{array}$ \\
\hline None & 100.00 & PMSF & 0.00 \\
$\mathrm{Mn}^{2+}$ & $104.85 \pm 2.33$ & EDTA & $89.89 \pm 1.91$ \\
$\mathrm{Mg}^{2+}$ & $119.14 \pm 2.74$ & EGTA & $87.24 \pm 1.84$ \\
$\mathrm{Co}^{2+}$ & $92.65 \pm 1.99$ & SDS & $92.65 \pm 1.99$ \\
$\mathrm{~K}^{+}$ & $87.24 \pm 1.84$ & & \\
$\mathrm{Zn}^{2+}$ & $75.38 \pm 1.52$ & & \\
$\mathrm{Na}^{+}$ & $101.62 \pm 2.24$ & & \\
$\mathrm{Ca}^{2+}$ & $108.21 \pm 2.42$ & & \\
$\mathrm{Fe}^{3+}$ & $71.23 \pm 1.41$ & & \\
\hline
\end{tabular}


A

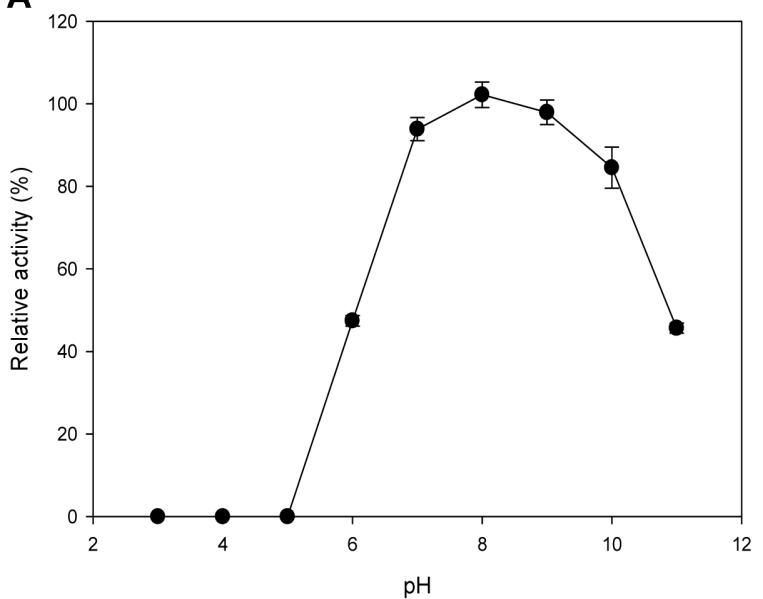

C

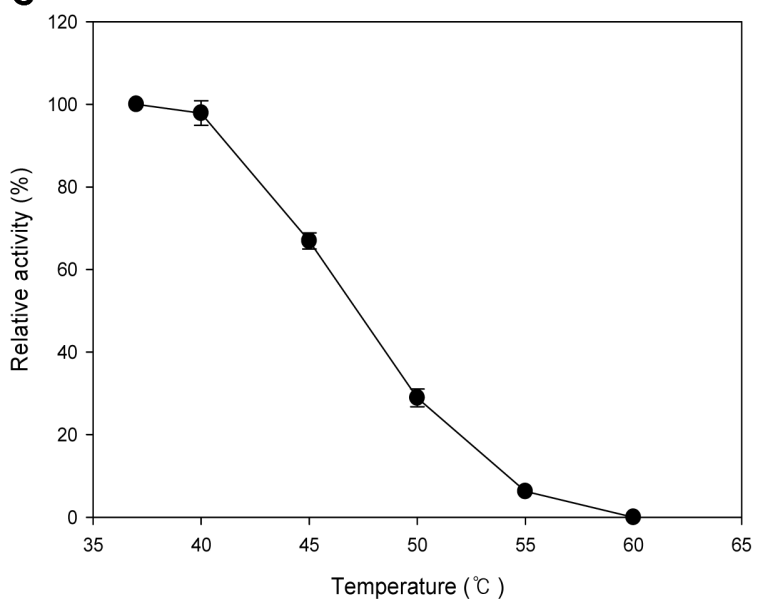

B

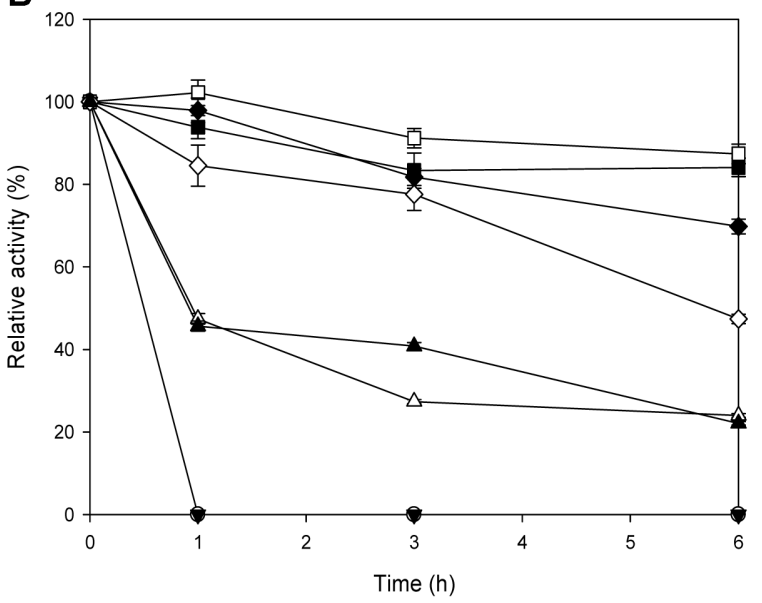

D

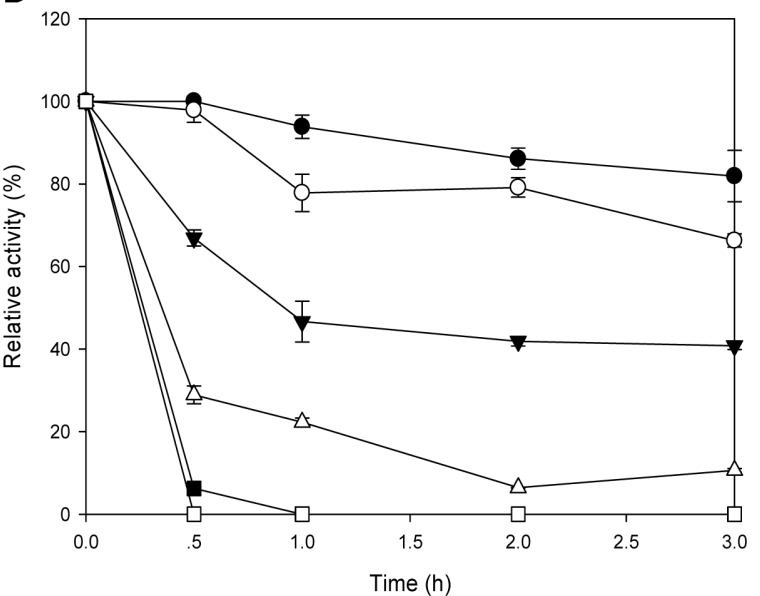

Fig. 7. The effect of $\mathrm{pH}$ and temperature on the fibrinolytic activity of AprEBS2.

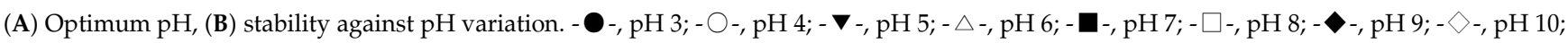
- $\mathbf{\Delta}$-, pH 11. (C) Optimum temperature, (D) stability against temperature. $-\mathbf{-}-37^{\circ} \mathrm{C} ;-\bigcirc-, 40^{\circ} \mathrm{C} ;-\nabla-, 45^{\circ} \mathrm{C} ;-\triangle-, 50^{\circ} \mathrm{C} ;-\mathbf{\square}-, 55^{\circ} \mathrm{C} ;-\square-, 60^{\circ} \mathrm{C}$.

Amidolytic Activity Measurements and Enzyme Kinetics

$\mathrm{K}_{\mathrm{m}}$ and $\mathrm{V}_{\max }$ of purified AprEBS2 were determined from the initial rates for the hydrolysis of N-succinyl-Ala-AlaPro-Phe-pNA. The $K_{m}$ and $V_{\max }$ values were $0.15 \mathrm{mM}$ and $39.68 \mu \mathrm{M} / 1 / \mathrm{min}$, respectively, and the $\mathrm{K}_{\text {cat }}$ was $18.14 \mathrm{~S}^{-1}$. $\mathrm{K}_{\text {cat }} / \mathrm{K}_{\mathrm{m}}$ was $1.25 \times 10^{5} \mathrm{~S}^{-1} \mathrm{M}^{-1}$. The values seemed similar to those of some other fibrinolytic enzymes reported elsewhere. The $\mathrm{K}_{\mathrm{cat}} / \mathrm{K}_{\mathrm{m}}$ value was similar to that of subtilisin FS33 $\left(1.56 \times 10^{5} \mathrm{~S}^{-1} \mathrm{M}^{-1}\right)$ [33].

\section{Hydrolysis of Fibrinogen by AprEBS2}

AprEBS2 quickly degraded $\mathrm{A}_{\alpha}$ and $\mathrm{B}_{\beta}$ chains of fibrinogen (Fig. 8). The $A_{\alpha}$ chain was the most sensitive and quickly hydrolyzed in $10 \mathrm{~min}$. Most $\mathrm{B}_{\beta}$ chain was degraded in 20 min and completely degraded in $30 \mathrm{~min}$. AprEBS2 has strong $\alpha$-fibrinogenase, moderate $\beta$-fibrinogenase, and also some $\gamma$-fibrinogenase activity. Compared with the control (no enzyme treatment, lane 1), the $\gamma$ chain was significantly degraded after $6 \mathrm{~h}$ incubation (lane 9). The hydrolysis pattern was similar to that observed in AprECB1, a fibrinolytic enzyme produced from Bacillus amyloliquefaciens CB1 [27]. But AprEBS2 shows some $\gamma$-fibrinogenase activity.

Considering its high fibrinolytic activity, salt tolerance, ability to grow at $10^{\circ} \mathrm{C}$, and antimicrobial activity, B. velezensis $\mathrm{BS} 2$ seems promising as a starter for jeotgal and other fermented foods where $\mathrm{NaCl}$ content does not exceed $17 \%$ but its effects on the quality of jeotgal needs to be studied in detail in the future. 


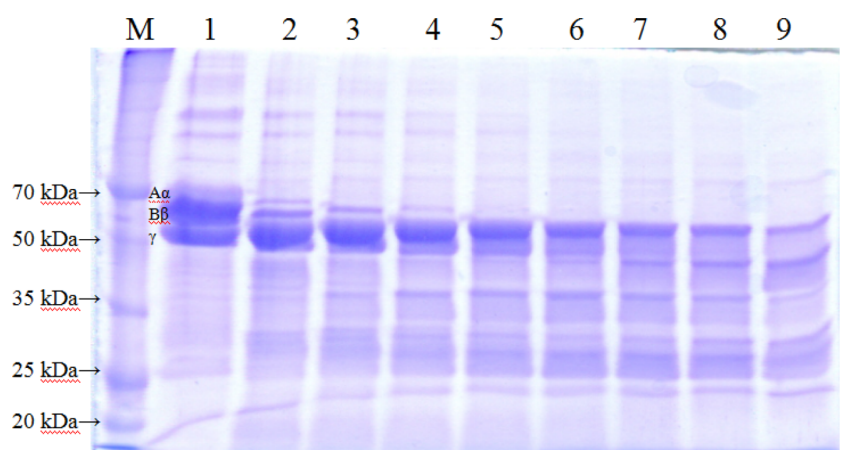

Fig. 8. Fibrinogen hydrolysis by AprEBS2.

M, DokDo-Marker, broad-range (EBM-1034, ELPIS, Deajeon, Korea); 1, control (no enzyme treatment); 2, $5 \mathrm{~min} ; 3,10 \mathrm{~min} ; 4,20 \mathrm{~min}$; , $30 \mathrm{~min} ; 6,1 \mathrm{~h} ; 7,2 \mathrm{~h} ; 8,3 \mathrm{~h} ; 9,6 \mathrm{~h}$. A 10\% acrylamide gel was used.

\section{Acknowledgments}

This work was supported by grant 20130290 to Solar Salt Research Center of Mokpo National University from the Ministry of Oceans and Fisheries of Korea, and also by the Basic Science Research Program through the National Research Foundation of Korea (NRF) funded by the Ministry of Education (2017R1D1A1B03030037). Zhuang Yao and Jeong-A Kim were supported by the BK21 PLUS program, MOE, Republic of Korea.

\section{Conflict of Interest}

The authors have no financial conflicts of interest to declare.

\section{References}

1. Koo OK, Lee SJ, Chung KR, Jang DJ, Yang HJ, Kwon DY. 2016. Korean traditional fermented fish products: jeotgal. J. Ethn. Foods 3: 107-116.

2. Guan L, Cho KH, Lee JH. 2011. Analysis of the cultivable bacterial community in jeotgal, a Korean salted and fermented seafood, and identification of its dominant bacteria. Food Microbiol. 28: 101-113.

3. Fukui Y, Yoshida M, Shozen KI, Funatsu Y, Takano T, Oikawa $\mathrm{H}$, et al. 2012. Bacterial communities in fish sauce mash using culture-dependent and -independent methods. J. Gen. Microbiol. 58: 273-281.

4. Han KI, Kim YH, Hwang SG, Jung EG, Patnaik BB, Han YS, et al. 2014. Bacterial community dynamics of salted and fermented shrimp based on denaturing gradient gel electrophoresis. J. Food Sci. 79: M2516-M2522.

5. Lee SH, Jung JY, Jeon CO. 2015. Bacterial community dynamics and metabolite changes in myeolchi-aekjeot, a
Korean traditional fermented fish sauce, during fermentation. Int. J. Food Microbiol. 203: 15-22.

6. Lee Y, Cho Y, Kim E, Kim HJ, Kim HY. 2018. Identification of lactic acid bacteria in galchi- and myeolchi-jeotgal by $16 \mathrm{~S}$ rRNA gene sequencing, MALDI-TOF mass spectrometry, and PCR-DGGE. J. Microbiol. Biotechnol. 28: 1112-1121.

7. Yongsawatdigul J, Rodtong S. Raksakulthai N. 2007. Acceleration of Thai fish sauce fermentation using proteinases and bacterial starter cultures. J. Food Sci. 72: 382-390.

8. Udomsil N, Rodtong S, Choi YJ, Hua Y, Yongsawatdigul J. 2011. Use of Tetragenococcus halophilus as a starter culture for flavor improvement in fish sauce fermentation. J. Agric. Food Chem. 59: 8401-8408.

9. Yoshikawa S, Kurihara H, Kawai Y, Yamazaki K, Tanaka A, Nishikiori T, Ohta T. 2010. Effect of halotolerant starter microorganisms on chemical characteristics of fermented chum salmon (Oncorhynchus keta) sauce. J. Agric. Food Chem. 58: 6410-6417.

10. Weng Y, Yao J, Sparks S, Wang KY. 2017. Nattokinase: an oral antithrombotic agent for the prevention of cardiovascular disease. Int. J. Mol. Sci. 18: 523

11. Cai D, Zhu C, Chen S. 2017. Microbial production of nattokinase: current progress, challenge and prospect. World J. Microbiol. Biotechnol. 33: 84.

12. Mine Y, Wong AHK, Jiang B. 2005. Fibrinolytic enzymes in Asian traditional fermented foods. Food Res. Int. 38: 243-250.

13. Kim JA, Yao Z, Kim HJ, Kim JH. 2018. Properties of gul jeotgal (oyster jeotgal) prepared with different types of salt and Bacillus subtilis JS2 as starter. Microbiol. Biotechnol. Lett. 46: $1-8$.

14. Yao Z, Liu X, Shim JM, Lee KW, Kim HJ, Kim JH. 2017. Properties of a fibrinolytic enzyme secreted by Bacillus amyloliquefaciens RSB34, isolated from Doenjang. J. Microbiol. Biotechnol. 27: 9-18.

15. Kwon GH, Lee HA, Park JY, Kim JS, Lim JK, Park CS, et al. 2009. Development of a RAPD-PCR method for identification of Bacillus species isolated from cheonggukjang. Int. J. Food Microbiol. 129: 282-287.

16. Kim GM, Lee AR, Lee KW, Park JY, Chun J, Cha J, et al. 2009. Characterization of a $27 \mathrm{kDa}$ fibrinolytic enzyme from Bacillus amyloliquefaciens CH51 isolated from cheonggukjang. J. Microbiol. Biotechnol. 19: 997-1004.

17. Dower WJ, Miller JF, Ragsdale CW. 1988. High efficiency transformation of $E$. coli by high voltage electroporation. Nuclelic Acids Res. 16: 6127-6145.

18. Sambrook J, Russel DW. 2001. Molecular Cloning: A Laboratory Manual, 3rd Ed. Cold Spring Harbor Laboratory Press, Cold Spring Harbor, NY, USA.

19. Bradford MM. 1976. Rapid and sensitive methods for the quantification of microgram quantities of protein utilizing the principle of protein -dye binding. Anal. Biochem. 72: 248-254.

20. Fan B, Blom J, Klenk HP, Borriss R. 2017. Bacillus amyloliquefaciens, Bacillus velezensis, and Bacillus siamensis 
form an operational group B. amyloliquefaciens" within the B. subtilis species complex. Front. Microbiol. Doi. 10.3389/ fmicb.2017.00022

21. Dunlap CA, Kim SJ, Kwon SW, Rooney AP. 2016. Bacillus velezensis is not a later heterotypic synonym of Bacillus amyloliquefaciens; Bacillus methylotrophicus, Bacillus amyloliquefaciens subsp. plantarum and 'Bacillus oryzicola' are later heterotypic synonyms of Bacillus velezensis based on phylogenomics. Int. J. Syst. Evol. Microbiol. 66: 1212-1217.

22. Palazzini JM, Dunlap CA, Bowman MJ, Chulze SN. 2016. Bacillus velezensis RC218 as a biocontrol agent to reduce Fusarium head blight and deoxynivalenol accumulation: genome sequencing and secondary metabolite cluster profiles. Microbiol. Res. 191: 30-36.

23. Chen L, Heng J, Qin S, Bian K. 2018. A comprehensive understanding of the biocontrol potential of Bacillus velezensis LM2303 against Fusarium head blight. PLoS One 13: e0198560.

24. Kim BK, Kim HJ, Lee JW. 2013. Rapid statistical optimization of cultural conditions for mass production of carboxymethylcellulase by a newly isolated marine bacterium, Bacillus velezensis A-68 from rice hulls. J. Life Sci. 23: 757-769.

25. Liu X, Ren B, Chen M, Wang H, Kokare CR, Zhou X, et al. 2010. Production and characterization of a group of bioemulsifiers from the marine Bacillus velezensis strain $\mathrm{H} 3$. Appl. Microbiol. Biotechnol. 87: 1881-1893.

26. Yao Z, Kim JA, Kim JH. 2018. Gene cloning, expression, and properties of a fibrinolytic enzyme secreted by Bacillus pumilus BS15 isolated from gul (oyster) jeotgal. Biotechnol. Bioprocess Eng. 23: 293-301.

27. Heo K, Cho KM, Lee CK, Kim GM, Shin JH, Kim JS, et al. 2013. Characterization of a fibrinolytic enzyme secreted by Bacillus amyloliquefaciens CB1 and its gene cloning. J. Microbiol. Biotechnol 23: 974-983.

28. Jo HD, Lee HA, Jeong SJ, Kim JH. 2011. Purification and characterization of a major fibrinolytic enzyme from Bacillus amyloliquefaciens MJ5-41 isolated from meju. J. Microbiol. Biotechnol. 21: 1166-1173.

29. Peng Y, Yang X, Zhang Y. 2005. Microbial fibrinolytic enzymes: an overview of source, production, properties, and thrombolytic activity in vivo. Appl. Microbiol. Biotechnol. 69: 126-132.

30. Wu XC, Lee W, Tran L, Wong SL. 1991. Engineering a Bacillus subtilis expression-secretion system with a strain deficient in six extracellular proteases. J. Bacteriol. 173: 49524958.

31. Jeong SJ, Heo K, Park JY, Lee KW, Park JY, Joo SH, et al. 2015. Characterization of AprE176, a fibrinolytic enzyme from Bacillus subtilis HK176. J. Microbiol. Biotechnol. 25: 89-97.

32. Kim W, Choi K, Kim Y, Park H, Choi J, Lee Y, et al. 1996. Purification and characterization of a fibrinolytic enzyme produced from Bacillus sp. strain CK 11-4 screened from Chungkook-Jang. Appl. Environ. Microbiol. 62: 2482-2488.

33. Wang CT, Ji BP, Li B, Nout R, Li PL, Ji H, et al. 2006. Purification and characterization of a fibrinolytic enzyme of Bacillus subtilis DC33, isolated from Chinese traditional Douchi. J. Ind. Microbiol. Biotechnol. 33: 750-758. 